\title{
Variable responses of seabirds to change in marine climate: California Current, 1985-1994
}

\author{
Cornelia S. Oedekoven*, David G. Ainley, Larry B. Spear
}

H. T. Harvey \& Associates, 3150 Almaden Expwy, Suite 145, San Jose, California 95118, USA

\begin{abstract}
We conducted annual ship-board surveys to determine the density and distribution of seabirds off central California in relation to marine climate, from 1985 to 1994. Summarized here are results for the sooty shearwater Puffinus griseus, the common murre Uria aalge, and Cassin's auklet Ptychoramphus aleuticus, the 3 most abundant seabirds in the central part of the California Current (91\% of seabird abundance and biomass). During the study, sea-surface temperature, wind speed and thermocline depth all increased, salinity decreased and thermocline intensity (slope) showed no consistent trend. Periods of cool water and warm water, as well as offshore and inshore excursions of the shelfbreak front, alternated and were mediated by the Southern Oscillation and upwelling intensity. The responses to climate variation by the 3 seabird species were in accord with their respective morphologies and natural history patterns. All moved closer to shore and away from the shelf-break front (which also weakened). Abundance of the shallow-diving shearwater and auklet decreased dramatically, but those of the deeper-diving murre did not. The shearwater, which nests in the southern hemisphere and is the most mobile of the 3 seabirds, likely changed its migration routes and reduced its association with the California Current. The auklet, which breeds within the study area and lacks mobility, declined in number, most likely due to reduced breeding success and subsequent reduced population size. Remaining auklets moved away from the shelfbreak, but not as far inshore as the shearwater. The murre, which also breeds locally, is the most adaptable owing to its deeperdiving capabilities. It shifted distribution within the study area to feed on alternative prey found throughout the water column.
\end{abstract}

KEY WORDS: Aleutian Low Pressure System · Cassin's auklet · Climate change $\cdot$ Common murre El Niño $\cdot$ La Niña $\cdot$ Sooty shearwater $\cdot$ Upwelling

\section{INTRODUCTION}

The California Current possesses a large and diverse seabird fauna (Ainley 1976, Briggs et al. 1987), but is well known also for a varying climate (e.g. Hickey 1979, Chelton 1981, McLain et al. 1985, Roemich \& McGowan 1995, Hayward et al. 1996, McGowan et al. 1996, Mantua et al. 1997). Several California Current studies have reported responses of seabirds to short-

*Present address: Southwest Fisheries Science Center, La Jolla, California 92037-0271, USA.

E-mail: coedekoven@yahoo.com term climatic change brought about by warm-water events (Chelton et al. 1982, Briggs et al. 1987, Ainley et al. 1994, 1995b, Allen 1994), as well as responses to decadal climatic patterns (Ainley et al. 1995a,b, Veit et al. 1996, Ainley \& Divoky 2000).

Here, we examine variation in the types of responses exhibited by top-level predators to changes in marine climate through investigations carried out in the central portion of the California Current, 1985 to 1994. We consider patterns evident during El Niño and La Niña phases of the Southern Oscillation (SO), but also focus on longer-term changes. Specifically, our study took place during a long-term warming phase in the eastern Pacific, when several warm-water events also oc- 


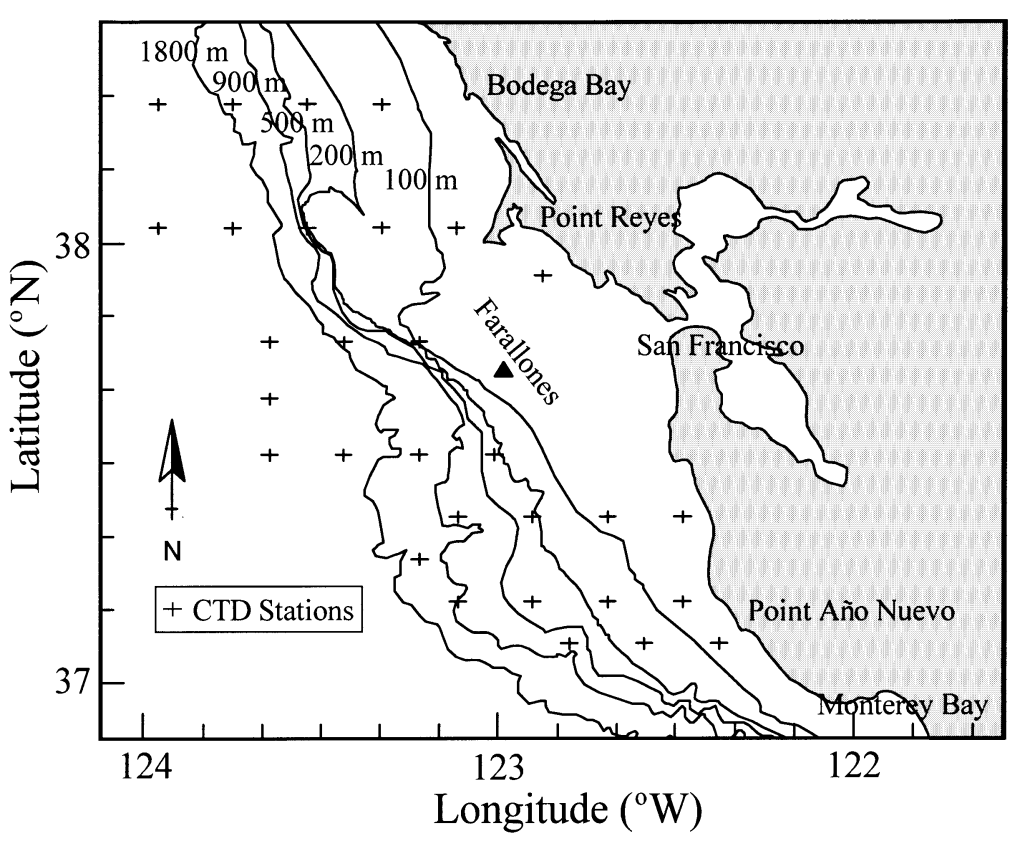

Fig. 1. Study area showing locations of CTD stations
Upwelling conditions in the study area are often perturbed. Especially strong upwellingfavorable winds and a shallow thermocline lead to colder, more nutrient-rich waters than usual. Such conditions are called La Niña. Perturbations are also related to the occurrence of abnormally warm water. This leads to a deepening and an intensified stratification of the thermocline, in turn resulting in upwelling of warm, nutrient-depleted waters. Then, the main source of nutrients is restrained and the organisms composing the food chain decline (Barber \& Chavez 1983).

These warm-water events can be caused by several factors. One such factor is El Niño (Wyrtki 1975, Enfield 1981, Cane 1983), which results in warming of the upper $300 \mathrm{~m}$ of the water column in the California Current after a time lag of up to 6 mo (compared to its occurrence in the tropical Pacific; Norton \& McLain 1994). During our study, El Niño occurred during 1986/1987 and 1991 to 1993 (Trenberth 1997). The event in 1986/1987 was weak compared to that of 1991 to 1993.

curred. One strong La Niña occurred as well. These changes in the environment directly affected the lower and intermediate levels of the food web (e.g. Roemich \& McGowan 1995), and in turn, as we will show, clearly altered the distribution and abundance of higher trophic-level organisms.

Our analyses focus on trends in abundance and distribution of the 3 most abundant seabird species. These 'key species' included the sooty shearwater Puffinus griseus, the common murre Uria aalge, and Cassin's auklet Ptychoramphus aleuticus, which composed $90.6 \%$ of all individuals recorded $(50.4,21.3$, and $18.9 \%$ respectively; Oedekoven 1997). These species responded to changes in the environment in different ways due to different life histories, morphologies, and feeding habits.

\section{METHODS}

Oceanographic patterns of study area. Our study area included the Central California coast between 37.00 and $38.32^{\circ} \mathrm{N}$ and from the coast westward to $124.00^{\circ} \mathrm{W}$ (Fig. 1). Wind-driven, coastal upwelling is a major feature of this area (Bakun 1990). Two persistent upwelling centers also occur, one near the Point Reyes Peninsula and the other off Año Nuevo (Fig. 1). An along-shore shelfbreak front usually develops between relatively warm, low-salinity offshore water and cool, upwelled water, separating areas of low and high productivity (Schwing et al. 1991).
Warming of the California Current can also be related to the intensification of the Aleutian Low Pressure System. During times of intensified pressure, the prevailing northwesterly winds in the study area weaken, resulting in a weakened current flow, less upwelling of cold nutrient-rich waters, and the intrusion of warmer offshore waters into coastal areas (Norton \& McLain 1994). The effect is a warming of the upper $100 \mathrm{~m}$ of the water column. Both El Niño and intensification of the Aleutian Low Pressure System can reinforce one another, leading to extreme warming (Simpson 1992) such as during 1992/1993. Finally, the climate of the eastern Pacific also changes on a larger time scale during Pacific Decadal Oscillations (Mantua et al. 1997). For example, in 1976/1977, a climate shift in the Pacific was caused by a southward relocation and intensification of the Aleutian Low Pressure System (Miller et al. 1994, Roemich \& McGowan 1995, McGowan et al. 1998). This brought increased sea-surface temperatures (SST) and decreased productivity in the eastern North Pacific during the following 3 decades.

Survey protocol. We conducted seabird surveys on 17 cruises conducted each year during the upwelling season (March to July), from 1985 to 1994. During daylight, while the ship was underway, we used the continuous strip-transect survey method (Tasker et al. 1984, Spear et al. 1992) to count seabirds that came within $300 \mathrm{~m}$ off one forward quarter of the vessel. Survey periods were divided into $15 \mathrm{~min}$ transects, except those terminated prematurely when the ship arrived at 
an oceanographic station. For each sighting we recorded species, number, and behavior. Behaviors included: (1) sitting on the water, (2) foraging (i.e. feeding, chasing prey, or circling over a potential food source), and (3) flying in a steady direction.

At the start of each transect we noted position, course, and ship speed. We also logged ocean depth, wind speed and direction, SST, sea-surface salinity (SSS), and thermocline depth and slope. We gathered thermocline information from temperature profiles obtained during conductivity-temperature-depth (CTD) casts. Thermocline depth refers to the shallowest temperature inflection point as determined from CTD printouts. When there was no inflection, the thermocline depth was recorded as zero (at the ocean surface). When there was more than 1 inflection, we assumed that the thermocline began at the strongest inflection. We measured thermocline slope as the temperature difference (nearest $0.1^{\circ} \mathrm{C}$ ) between the thermocline to a point $20 \mathrm{~m}$ below it. The values for thermocline depth and slope were interpolated for each transect between stations.

We also recorded data on important spatial variables, including distances to the primary nesting colony on Southeast Farallon Island (SEFI at $37.70^{\circ} \mathrm{N}$, $123.00^{\circ} \mathrm{W}$ ), to the nearest point on the mainland, and to the shelfbreak (the $200 \mathrm{~m}$ isobath). SEFI is by far the largest seabird breeding colony in the area, in fact one of the largest on the Pacific coast of North America (Ainley \& Boekelheide 1990), and influences the distribution of resident species (Allen 1994). For analyzing the relationship between bird distributions and distance to the shelfbreak, we scored distances as negative or positive for locations inshore and offshore, respectively, of the $200 \mathrm{~m}$ isobath.

Data analysis. The area surveyed was calculated for each transect by multiplying the ship's speed by transect width and duration. In total, we conducted 3258 transects in $775.1 \mathrm{~h}$ of surveys over $4043.2 \mathrm{~km}^{2}$ of ocean surface. We calculated seabird density (birds $\mathrm{km}^{-2}$ ) per transect by dividing the number of birds recorded by the area surveyed. To examine the distribution of birds in relation to environmental affinities, we confined the analyses to birds that were foraging or sitting on the water (a behavior used by pursuit divers and other species that have recently fed in the vicinity). Hence, we excluded birds flying in a steady direction because they may not have been making use of the waters over which they were seen.

We used generalized additive models (GAMs: see Hastie \& Tibshirani 1990, Clarke et al. unpubl.) to examine trends in abundance of each species across years in order to deal with non-random survey effort in combination with the non-random distributions of species. GAMs, being model- rather than sample-based, over- come such bias. They also capture complex nonlinear trends in density while using only a few parameters. Specifically, only 4 independent variables (latitude, longitude, ocean depth, distance to the mainland) were initially included in each analysis. Therefore, besides increasing the accuracy, they considerably increase the precision of abundance estimates, thus improving the researchers' ability to detect temporal trends among biota that have extremely variable (clumped) distributions. The dependent term used in these models was density for each 15 min transect.

The primary objective of this study was to determine how the relationship between seabird density and environmental variables changed across years, or with change in another variable. Because GAMs have not yet been sufficiently developed to investigate interactions between independent variables (E. Clarke pers. comm.), detailed examination of the relationship between seabird distributions and temporal/environmental variables was done using linear regression (STATA Corp. 1995), and was limited to the most important explanatory variables for each species. Identification of the latter was done using principal components (PC) analyses, whereby a separate analysis was performed for each of the 3 species. Each record (15 min transect) was weighted with the log-transformed density value. The 'important' temporal and environmental variables were defined as those that scored \pm 0.40 on the first or second PC axes.

Next, we used the regression analyses to examine interactions between the important temporal and environmental variables identified for each key species. However, a simple interaction with year only tells us that the relationship (i.e. positive vs negative slope coefficients) between density and the variable differed between years, but not about the possible trend in such a difference (i.e. increasing positive or decreasing negative coefficients) across years (see Seber 1977). Therefore, the models we used to detect annual trends in coefficient values (for the relationship between density and the environmental variable) included 3 main effects (the environmental term, categorical-year, and linear-year) and the (fourth) interaction-term: linearyear $\times$ the environmental variable. Second- and thirdorder polynomials for the interaction-terms were also included to test for curvilinearity in the annual trend. A curvilinear interaction term included the oceanographic variable multiplied by the quadratic or cubic continuous-year. A similar procedure was used for interactions including 2 environmental variables. All environmental variables were analyzed as continuous.

We showed these relationships by plotting regression coefficients for the relationship between respective variables and density, stratified by year. When interactions occurred between 2 environmental vari- 
ables, we plotted regression coefficients for the relationship between 1 of the environmental variables and density for categories of the second environmental variable.

\section{RESULTS}

\section{Relationship between year and oceanographic variables}

Significant correlations existed between all combinations of pairs of oceanographic variables (all p < 0.05, Table 1). Particularly strong relationships occurred among SST, SSS, and thermocline slope. SSS decreased and thermocline slope increased with increase in SST. To reduce this problem, we excluded SSS from the PC analyses. The strong correlation between SST and thermocline slope will be taken into account when interpreting the results.
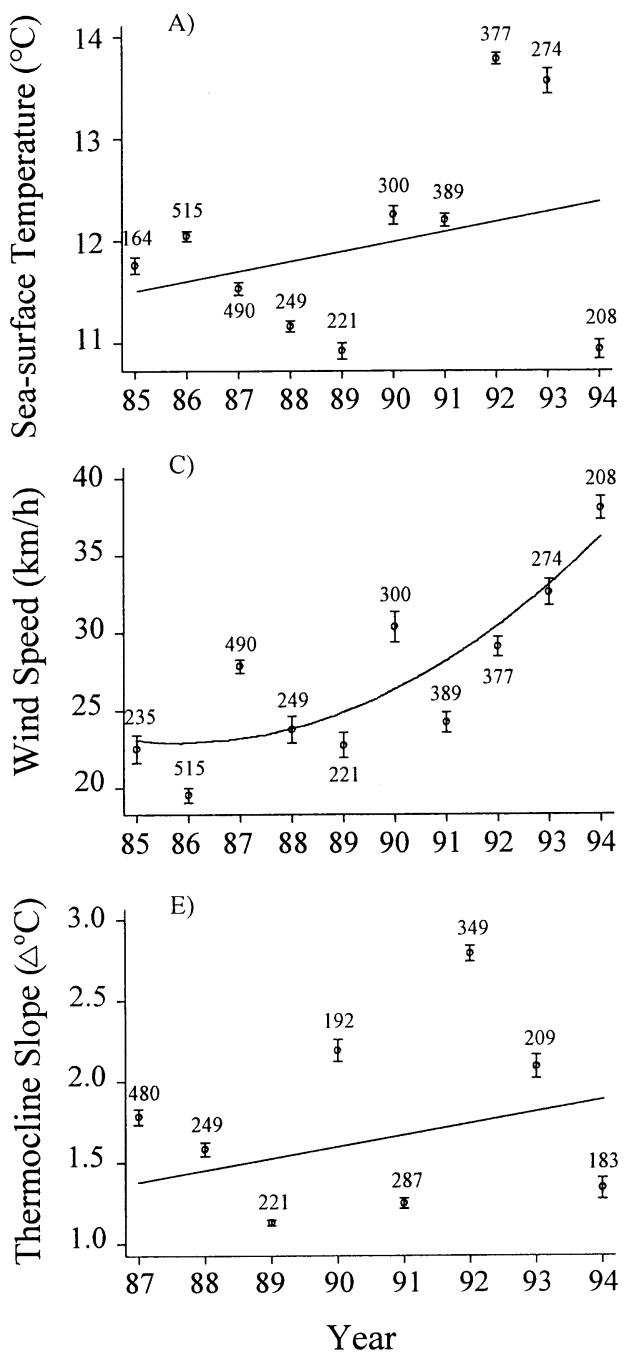

Table 1. Correlation coefficients (r-values) for relationships between oceanographic variables sea-surface temperature (SST), sea-surface salinity (SSS), wind speed (WSP), thermocline depth (TDPT), and thermocline slope (TSLP). Sample size (number of 15 min transects) was 2161

\begin{tabular}{|lrrrr|}
\hline & SST & SSS & WSP & TDPT \\
\hline SSS & -0.588 & & & \\
WSP & -0.111 & -0.056 & & \\
TDPT & -0.208 & 0.083 & 0.184 & \\
TSLP & 0.589 & -0.347 & 0.051 & -0.210 \\
\hline
\end{tabular}

Regression analyses revealed significant linear relationships between year and each of the 4 oceanographic variables, including SST and SSS, thermocline depth and wind speed (Table 2, Fig. 2A-D). Of five variables, 3 (SST, wind speed, and thermocline depth) increased and 1 variable (SSS) decreased significantly with year. The regression between year and thermo-
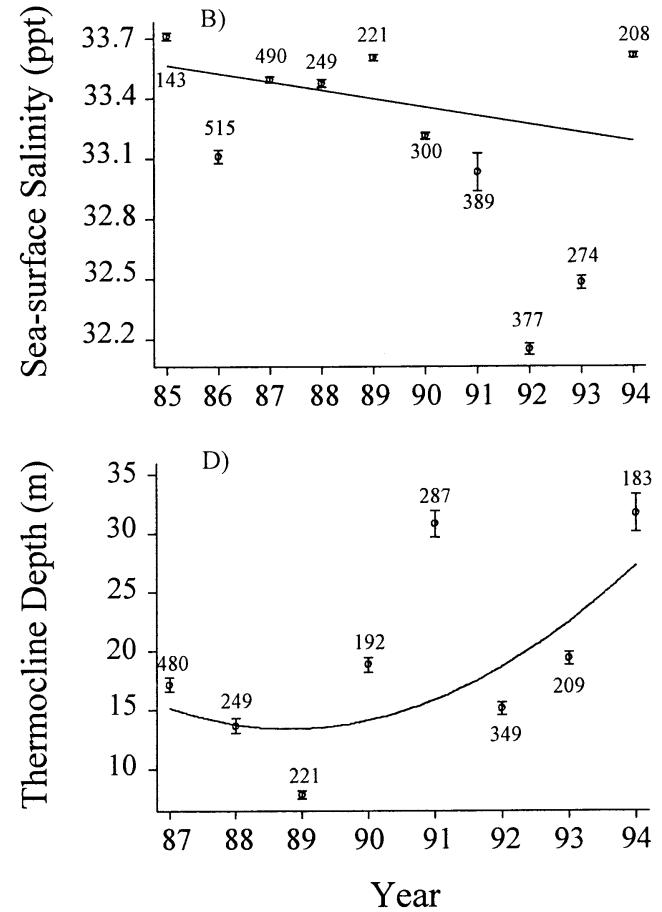

Fig. 2. Means of oceanographic variables monitored during 1985 to 1994. (○) Means; vertical bars: $\pm 1 \mathrm{SE}$; lines of best fit: relationships between the variables and year; numbers next to bars: sample sizes 
Table 2. Regression coefficients, standard error, F- and p-values from multiple-regression analyses for relationship of 5 oceanographic variables with year (year analyzed as continuous). Variable Julian date (JD) was included to control for between-year differences in survey timing. Only significant terms are reported. Sample size was 3187 in (A) and (C), 3166 in (B), and 2161 in (D) and (E). Variation in sample sizes was due to missing data for some of the oceanographic variables. All numerator df $=1$

\begin{tabular}{|c|c|c|c|}
\hline Term & Coefficient $\pm \mathrm{SE}$ & $F$-value & p-value \\
\hline \multicolumn{4}{|c|}{ (A) Sea-surface temperature, $\mathrm{r}^{2}=0.090$} \\
\hline Year & $0.0106 \pm 0.0106$ & 99.50 & $<0.001$ \\
\hline JD & $0.014 \pm 0.0015$ & 93.02 & $<0.001$ \\
\hline \multicolumn{4}{|c|}{ (B) Sea-surface salinity, $\mathrm{r}^{2}=0.073$} \\
\hline Year & $-0.0097 \pm 0.0062$ & 241.27 & $<0.001$ \\
\hline JD & $0.0030 \pm 0.00088$ & 11.98 & $<0.001$ \\
\hline \multicolumn{4}{|c|}{ (C) Wind speed, $\mathrm{r}^{2}=0.088$} \\
\hline Year & $1.40 \pm 0.083$ & 286.13 & $<0.001$ \\
\hline Year $^{2}$ & $0.164 \pm 0.0364$ & 20.38 & $<0.001$ \\
\hline \multicolumn{4}{|c|}{ (D) Thermocline depth, $\mathrm{r}^{2}=0.072$} \\
\hline Year & $1.72 \pm 0.051$ & 129.74 & $<0.001$ \\
\hline Year $^{2}$ & $0.340 \pm 0.675$ & 25.38 & $<0.001$ \\
\hline JD & $-0.047 \pm 0.193$ & 5.90 & 0.02 \\
\hline \multicolumn{4}{|c|}{ (E) Thermocline slope, $\mathrm{r}^{2}=0.101$} \\
\hline Year & $-0.019 \pm 0.0102$ & 3.54 & 0.06 \\
\hline JD & $0.018 \pm 0.0013$ & 202.62 & $<0.001$ \\
\hline
\end{tabular}

cline slope showed a marginally insignificant positive trend ( $p=0.06$; Fig. 2E).

Wind speed and thermocline depth also had significant quadratic relationships with year (Table 2C,D, Fig. 2C,D). Wind speed was low and variable from 1985 to 1989 , followed by an increase to 1994 . The relationship between thermocline depth and year was similar.

With the exception of 1994, SST and SSS also showed dramatic increases and decreases, respectively, after 1989 (Fig. 2A,B). Similarly, the steepest thermocline slopes were observed in 1990, 1992, and 1993 (Fig. 2E).

Thus, when SST was low between 1985 and 1989, SSS was high and thermocline depth was shallow, indicating the presence of well-mixed, upwelled waters. Between 1990 and 1994, mixing in the water column lessened, as indicated by the increase in thermocline depth. The occurrence of the highest mean values for SST and thermocline slope, and lowest values for SSS, during 1990, 1992, and 1993, also indicate the presence of a distinct warm-water surface layer and decreased upwelling in the later part of the study.

\section{Annual trends in seabird abundance}

Abundances of the sooty shearwater (Puffinus griseus) and Cassin's auklet (Ptychoramphus aleuticus) declined significantly between 1985 and 1994 (Fig. 3A,C). Densities of the shearwater were highest in 1985, 1987 to 1989 , and lowest in 1986 and 1990 to 1994. Auklet densities showed a quadratic relationship with year due to stability from 1985 to 1988, followed by a rapid decline between 1989 and 1994. Although there was no significant linear annual trend in abundance for the
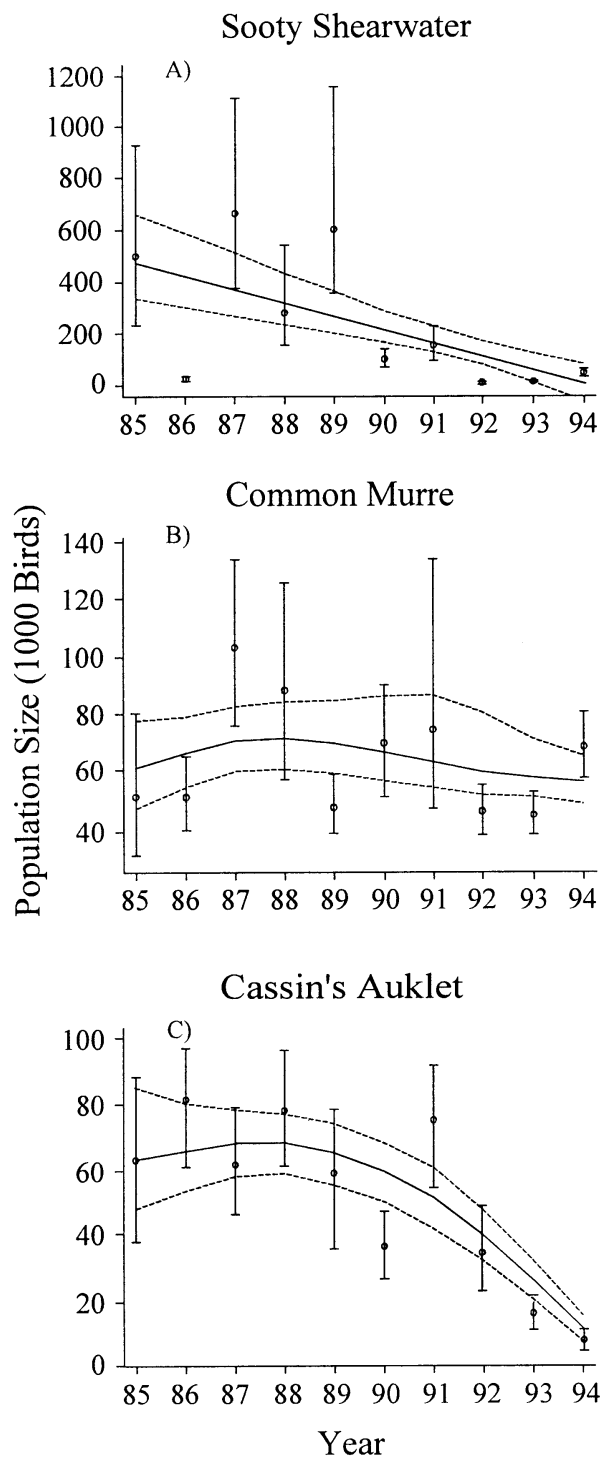

Fig. 3. Puffinus griseus, Uria aalge, and Ptychoramphus aleuticus. Population size estimates of the 3 most abundant seabird species within the study area, 1985 to 1994. () Estimates; vertical bars: confidence intervals for a given year; continuous lines: best fit for the relationship between population size and year; dashed lines: confidence intervals for the acrossyear relationship. See Fig. 2A for sample sizes 
common murre (Uria aalge), the relationship was quadratic because of elevated densities observed in 1987 and 1988 (Fig. 3B).

\section{Relationship between seabird density and environmental variables}

The first and second PC axes explained 52, 58, and $55 \%$ of the variation in density of the shearwater, murre and auklet, respectively (Table 3). Variables with scores greater than \pm 0.40 on the 2 axes (hereafter 'key variables') were, for both the shearwater and the murre, SST, thermocline slope, distance from the shelfbreak, distance from land, and distance from SEFI. For the auklet, key variables were SST, thermocline slope, distance from the shelfbreak, distance from land, and ocean depth.

The regression analyses revealed 2-way interactions for the effects of key variables on each species: 5 for the shearwater, 7 for the murre, and 3 for the auklet (Table 4). Two interactions, year $\times$ SST and year $\times$ dis-

Table 3. Puffinus griseus, Uria aalge, and Ptychoramphus aleuticus. Principal components (PC) analysis for the 3 study species including eigenvalue (cumulative) proportions of variance explained by 8 environmental variables: ocean depth (DPT), distance to land (Land), to the shelfbreak (Shelf), and to Southeast Farallon Island (SEFI), wind speed (WSP), sea-surface temperature (SST), thermocline depth (TDPT) and slope (TSLP). Sample size was 2161 transects. Values given for PC1 and PC2 pertain to first and second PC axes, respectively, and are the eigenvector loadings where the potential value range was 0.00 to 1.00

\begin{tabular}{|llllrr|}
\hline Component & Proportion & Cumulative & Variable & PC1 & PC2 \\
\hline Sooty shearwater & & & & & \\
1 & 0.33 & 0.33 & SST & -0.37 & 0.61 \\
2 & 0.19 & 0.52 & WSP & -0.09 & -0.15 \\
3 & 0.16 & 0.68 & TDPT & 0.22 & -0.05 \\
4 & 0.14 & 0.83 & TSLP & -0.42 & 0.32 \\
5 & 0.11 & 0.94 & Shelf & 0.53 & 0.45 \\
6 & 0.05 & 0.99 & Land & 0.57 & 0.31 \\
7 & 0.01 & 1.00 & SEFI & -0.13 & 0.45 \\
Common murre & & & & & \\
1 & 0.35 & 0.35 & SST & -0.40 & 0.43 \\
2 & 0.24 & 0.58 & WSP & 0.19 & -0.21 \\
3 & 0.15 & 0.73 & TDPT & 0.17 & -0.29 \\
4 & 0.12 & 0.85 & TSLP & -0.30 & 0.50 \\
5 & 0.09 & 0.94 & Shelf & 0.43 & 0.50 \\
6 & 0.06 & 0.99 & Land & 0.52 & 0.43 \\
7 & 0.01 & 1.00 & SEFI & -0.47 & 0.06 \\
Cassin's auklet & & & & & \\
1 & 0.33 & 0.33 & SST & 0.26 & 0.60 \\
2 & 0.22 & 0.55 & WSP & 0.02 & -0.18 \\
3 & 0.16 & 0.71 & TDPT & 0.08 & -0.27 \\
4 & 0.11 & 0.83 & TSLP & 0.12 & 0.60 \\
5 & 0.08 & 0.90 & DPT & 0.49 & -0.22 \\
6 & 0.06 & 0.95 & Shelf & 0.56 & -0.09 \\
8 & 0.03 & 0.99 & Land & 0.56 & -0.17 \\
& 0.01 & 1.00 & SEFI & 0.25 & 0.11 \\
\hline
\end{tabular}

tance from the shelfbreak, were common to all 3 species; 2 others (year $\times$ distance from land and SST $\times$ distance from the shelfbreak) were common to the shearwater and murre; and 1 (SST $\times$ distance from land) was common to the murre and auklet. For revity, statistical significance and values for regrescategories of SST and thermocline slope), but not coefficient values, are reported.

\section{Interactions between year and oceanographic variables}

SST

The regression coefficients for the relationship between SST and density of the sooty shearwater and common murre were significant during 5 and 7 of the $10 \mathrm{yr}$, (Tables $5 \& 6$ ). The significant, positive across-year patterns for this relationship for both species (Table 4, Fig. 4A,C) reflected a preference by these species for cooler waters in the earlier versus later years of the study. For the murre, this was primarily evident during 1991 and 1992, when this species actually preferred warmer waters. For the shearwater, there was generally no preference early in the study, compared to a preference for warmer waters in 4 of the $5 \mathrm{yr}$ after 1989.

In the case of the Cassin's auklet, regression coefficients for the relationship between density and SST were significantly negative in all years except 1985 and 1994, when there was no preference (Table 7). This indicated that, for a given year, this species selected cooler waters. There was no linear across-year pattern, but the relationship was cubic (Table 4, Fig. 4B). This pattern was due to the species' increasing preference for cooler waters between 1985 through 1988, stabilization between 1989 and 1991, and then slackening in the preference for cool waters to 1994 .

\section{Thermocline slope}

For the murre, the relationship between density and thermocline slope was negative in 6 of the $8 \mathrm{yr}$ in which thermocline slope was monitored (sig-

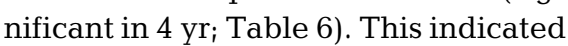


that murres preferred a less-stratified thermal structure. However, the across-year relationship between density and thermocline slope was significantly positive (Table 4, Fig. 4D), indicating that this preference decreased, or even reversed (1991 when the slope was positive) as the study progressed. There was no significant across-year pattern for the relationship between thermocline slope and auklet or shearwater densities (not shown).

\section{Interactions between year and spatial variables}

\section{Distance from shelfbreak}

The shearwater, murre and auklet were observed, on average, at various distances inshore from the shelfbreak in each year except 1988 (shearwater) and 1992 (auklet; Fig. 5). Thus, the significant, negative acrossyear patterns for the relationship between density and distance from the shelfbreak for each species (Table 4, Fig. 6A,C,E) indicated that their preference for inshore waters, either from farther offshore towards the shelfbreak, or farther inshore towards the mainland, increased as the study progressed (details below).
The positive, annual regression coefficients for the relationship between shearwater density and distance from the shelfbreak (significant in 1986, 1988, and 1989; Table 5) indicated increased density closer to the shelfbreak in 1986 and 1989 (but over deep water away from the shelf). Also indicated was increased density away from the shelfbreak and at greater distance from the shelfbreak during 1988 (Fig. 5A). In contrast, after 1989, the regression coefficient for the relationship between shearwater density and distance from the shelfbreak was negative (significant in 1992, 1993, and 1994; Table 5). This reflected an increase in shearwater density with greater distance shoreward of the shelfbreak (Fig. 5A). Thus, the shearwaters preferred waters near to, or just offshore of the shelfbreak early in the study, compared to preference for more inshore waters as the study progressed. This change in distribution shoreward was particularly evident in 1993 and 1994 .

For the murre, a species of inshore, shelf waters (Fig. 5B), the negative regression coefficients between density and distance from the shelfbreak (significant in each year; Table 6), indicated that densities increased toward shore, away from the shelfbreak. Like the shearwater, the increasingly negative slope (Fig. 6C)
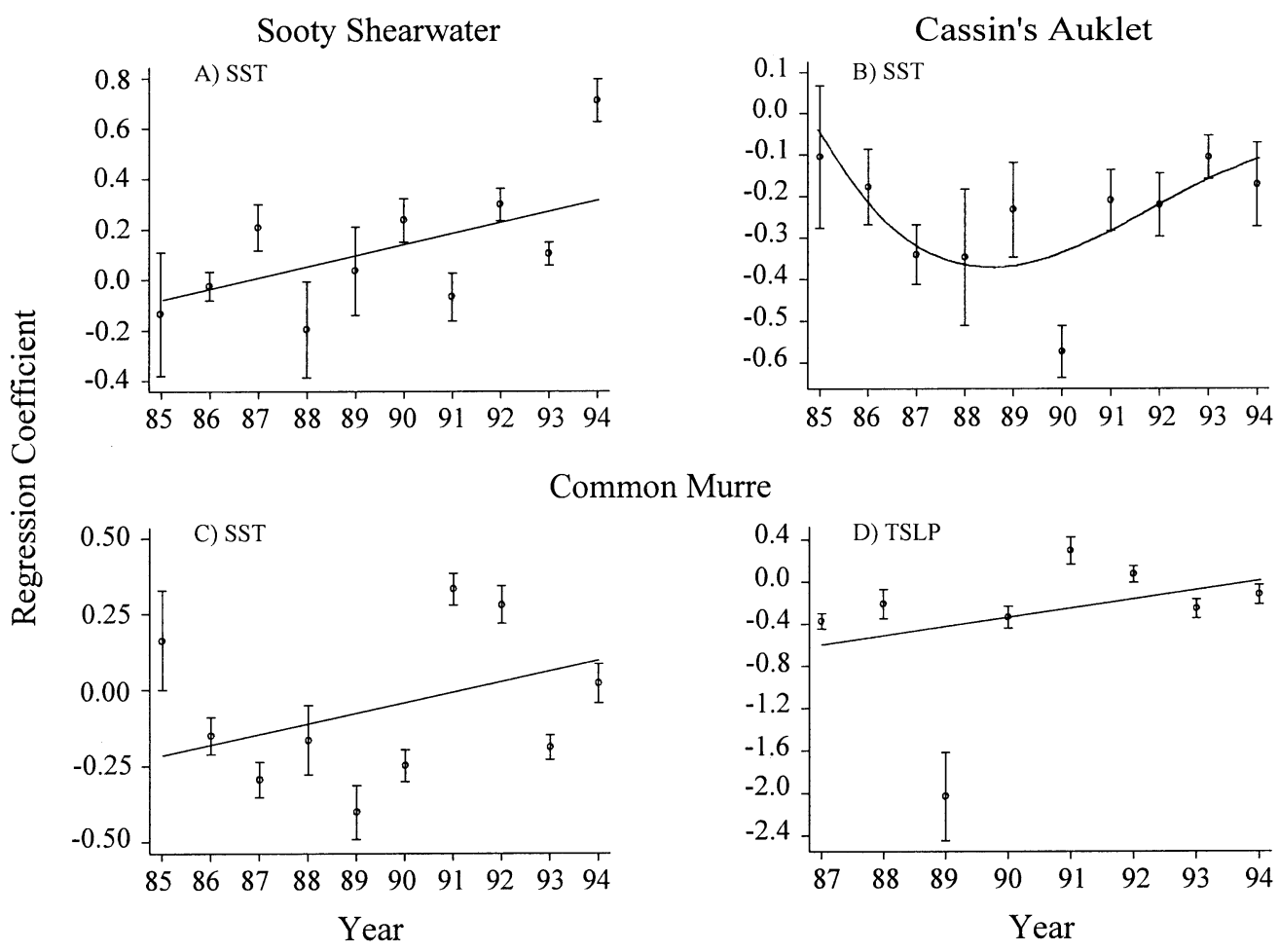

Common Murre sea-surface temperature (SST) and thermocline slope (TSLP, stratified by year, for the 3 seabird species. (o) Coefficient means; vertical bars: $\pm 1 \mathrm{SE}$; lines of best fit: relationships between coefficients and year. See Fig. 2A for sample sizes for A, B, C and Fig. 2D for sample sizes for D 
Table 4. Puffinus griseus, Uria aalge, and Ptychoramphus aleuticus. Regression coefficients, $F$-values, and p-values for the relationship between density of each of the predominant species (the dependent variable) and significant interaction terms including year and 5 key variables. See 'Methods' for analysis procedure. All numerator df $=1$

\begin{tabular}{|c|c|c|c|}
\hline Term & Coefficient $\pm \mathrm{SE}$ & $F$-value & $\mathrm{p}$-value \\
\hline \multicolumn{4}{|c|}{ Sooty shearwater } \\
\hline Year $\times$ SST & $0.030 \pm 0.0108$ & 7.59 & 0.006 \\
\hline Year $\times$ Shelf & $-0.0060 \pm 0.00070$ & 73.97 & $<0.001$ \\
\hline Year × Land & $-0.013 \pm 0.0014$ & 91.45 & $<0.001$ \\
\hline SST $\times$ Shelf & $-0.010 \pm 0.0012$ & 71.53 & $<0.001$ \\
\hline $\mathrm{SST}^{2} \times$ Shelf & $0.016 \pm 0.00042$ & 14.83 & $<0.001$ \\
\hline TSLP $\times$ SEFI & $-0.010 \pm 0.0045$ & 5.49 & 0.02 \\
\hline $\mathrm{TSLP}^{2} \times \mathrm{SEFI}$ & $-0.0051 \pm 0.0017$ & 8.84 & 0.003 \\
\hline \multicolumn{4}{|c|}{ Common murre } \\
\hline Year $\times$ SST & $0.044 \pm 0.095$ & 21.81 & $<0.001$ \\
\hline Year $\times$ TSLP & $0.062 \pm 0.0199$ & 9.70 & 0.002 \\
\hline Year × Shelf & $-0.0024 \pm 0.00061$ & 15.69 & $<0.001$ \\
\hline Year × Land & $-0.0033 \pm 0.0012$ & 7.52 & 0.006 \\
\hline Year $\times$ SEFI & $0.0088 \pm 0.0011$ & 62.35 & $<0.001$ \\
\hline SST $\times$ Shelf & $-0.0017 \pm 0.0010$ & 2.68 & 0.10 \\
\hline $\mathrm{SST}^{2} \times$ Shelf & $-0.00085 \pm 0.00035$ & 5.94 & 0.02 \\
\hline $\mathrm{SST}^{3} \times$ Shelf & $-0.00018 \pm 0.00010$ & 3.14 & 0.08 \\
\hline $\mathrm{SST}^{4} \times$ Shelf & $0.00014 \pm 0.000039$ & 13.26 & $<0.001$ \\
\hline SST $\times$ Land & $-0.0011 \pm 0.0021$ & 0.29 & 0.6 \\
\hline $\mathrm{SST}^{2} \times$ Land & $-0.00046 \pm 0.00070$ & 0.35 & 0.5 \\
\hline $\mathrm{SST}^{3} \times$ Land & $0.0012 \pm 0.00034$ & 12.57 & $<0.001$ \\
\hline \multicolumn{4}{|c|}{ Cassin's auklet } \\
\hline Year $\times$ SST & $0.015 \pm 0.0103$ & 1.97 & 0.16 \\
\hline Year $^{2} \times$ SST & $0.017 \pm 0.0047$ & 12.69 & $<0.001$ \\
\hline Year $^{3} \times$ SST & $0.00012 \pm 0.000035$ & 12.40 & $<0.001$ \\
\hline Year $\times$ Shelf & $-0.004 \pm 0.00068$ & 35.71 & $<0.001$ \\
\hline Year $^{2} \times$ Shelf & $0.00073 \pm 0.00031$ & 5.52 & 0.02 \\
\hline Year $^{3} \times$ Shelf & $5.72 \mathrm{E}-06 \pm 2.32 \mathrm{E}-06$ & 6.10 & 0.01 \\
\hline SST $\times$ Land & $-0.0095 \pm 0.00230$ & 16.93 & $<0.001$ \\
\hline $\mathrm{SST}^{2} \times$ Land & $0.0033 \pm 0.00081$ & 16.96 & $<0.001$ \\
\hline
\end{tabular}

indicated a movement further inshore as the study progressed. The inshore shift of their distribution was particularly evident after 1988, with the exception of 1991 (Fig. 5B).

For the auklet, the significant, positive regression coefficients for the relationship between density and distance from the shelfbreak during 1986, 1987, and 1988 (Table 7, Fig. 5C) reflected an increase in density from inshore areas towards the shelfbreak. In 1992, density increased with greater distance offshore of the shelfbreak. The negative regression coefficients for 1990 and 1991 indicated increased auklet density as distance increased inshore of the shelfbreak (Fig. 5C). In contrast to the shearwater and murre, the across-year pattern was cubic (Table 4, Fig. 6E). This resulted from the positive relationship from 1986 to 1988, a shift to a negative relationship from 1989 to 1991, and a lack of preference thereafter (with exception of the positive relationship in 1992). Thus, the inshore shift in the distribution of this species was most evident in 1989 and 1990 (see also Fig. 5C).

\section{Distance from land}

The across-year patterns for the relationship between density and distance from land for the shearwater and

Table 5. Puffinus griseus. Summary of interactions, including regression slope tendency (negative vs positive coefficients) and p-values for relationship between density of sooty shearwaters and environmental variables, given for the different strata designated for the second interaction variable. ns = insignificant (slope tendency not shown). All interaction terms analyzed as continuous

\begin{tabular}{|c|c|c|c|c|c|c|c|c|c|c|}
\hline Year & 1985 & 1986 & 1987 & 1988 & 1989 & 1990 & 1991 & 1992 & 1993 & 1994 \\
\hline SST & ns & ns & (+) 0.02 & ns & ns & (+) 0.01 & ns & $(+)<0.001$ & (+) 0.03 & $(+)<0.001$ \\
\hline Shelf & ns & $(+)<0.001$ & ns & $(+)<0.001$ & $+)<0.001$ & ns & ns & $(-)<0.026$ & $(-)<0.002$ & $(-)<0.001$ \\
\hline Land & ns & $(+)<0.001$ & ns & $(+)<0.001$ & $+)<0.001$ & $(-) 0.004$ & $(-) 0.012$ & $(-)<0.001$ & $(-)<0.001$ & $(-)<0.001$ \\
\hline \multicolumn{11}{|c|}{ SST stratum } \\
\hline & $9.3^{\circ} \mathrm{C}$ & \multicolumn{2}{|c|}{$10.5^{\circ} \mathrm{C}$} & $11.5^{\circ} \mathrm{C}$ & \multicolumn{2}{|c|}{$12.5^{\circ} \mathrm{C}$} & $13.5^{\circ} \mathrm{C}$ & \multicolumn{2}{|c|}{$14.5^{\circ} \mathrm{C}$} & $17.3^{\circ} \mathrm{C}$ \\
\hline Shelf & $(+)<0.001$ & \multicolumn{2}{|c|}{$(+)<0.001$} & $(+)<0.001$ & \multicolumn{2}{|c|}{ (-) 0.041} & (-) 0.004 & \multicolumn{2}{|c|}{ (-) 0.013} & ns \\
\hline \multicolumn{11}{|c|}{ Thermocline slope stratum } \\
\hline & $0.3 \Delta^{\circ} \mathrm{C}$ & $0.8 \Delta^{\circ} \mathrm{C}$ & $1.3 \Delta^{\circ} \mathrm{C}$ & $1.8 \Delta^{\circ} \mathrm{C}$ & $2.3 \Delta$ & & $.8 \Delta^{\circ} \mathrm{C}$ & $3.3 \Delta^{\circ} \mathrm{C}$ & $3.8 \Delta^{\circ} \mathrm{C}$ & $6.1 \Delta^{\circ} \mathrm{C}$ \\
\hline SEFI & ns & ns & (+) 0.011 & $(+)<0.001$ & $(-) 0$. & 005 & $\mathrm{~ns}$ & $-)<0.001$ & $\mathrm{~ns}$ & ns \\
\hline
\end{tabular}


murre were similar to those described for year versus distance from the shelfbreak (Table 4, Fig. 6B,D). For both species, there was a significant linear decrease in coefficients with year, indicating that shearwaters and murres moved closer to land as the study progressed (see also Tables $5 \& 6$ for slope tendency and significance).

\section{Distance from SEFI}

Coefficients for the relationship between density of the murre and distance from SEFI were negative in all years (significant except in 1992; Table 6). Therefore, densities increased with decreasing distance to the island. However, a significant, positive across-year pattern for the relationship between density and distance from SEFI (Table 4, Fig. 6) indicated that the relationship became weaker (i.e. the murres were distributed farther from SEFI) as the study progressed.

\section{Interactions between oceanographic and spatial variables}

SST $\times$ distance from shelfbreak

The across-SST pattern for the relationship between shearwater density and distance from the shelfbreak was significantly negative (see linear term; Table 4, Fig. 7A), reflecting the positive regression coefficients for SSTs, ranging from 8.5 to $12.0^{\circ} \mathrm{C}$, and negative coefficients for those from 12.1 to $15.0^{\circ} \mathrm{C}$ (Table 5). The pattern across the range of SSTs was also quadratic (Table 4, Fig. 7A), due to the positive relationship at lower SSTs, followed by a rapid decrease at SSTs of 12.1 to $13.0^{\circ} \mathrm{C}$, and then leveling at higher SSTs. Therefore, when SST was low, the shearwaters oc-
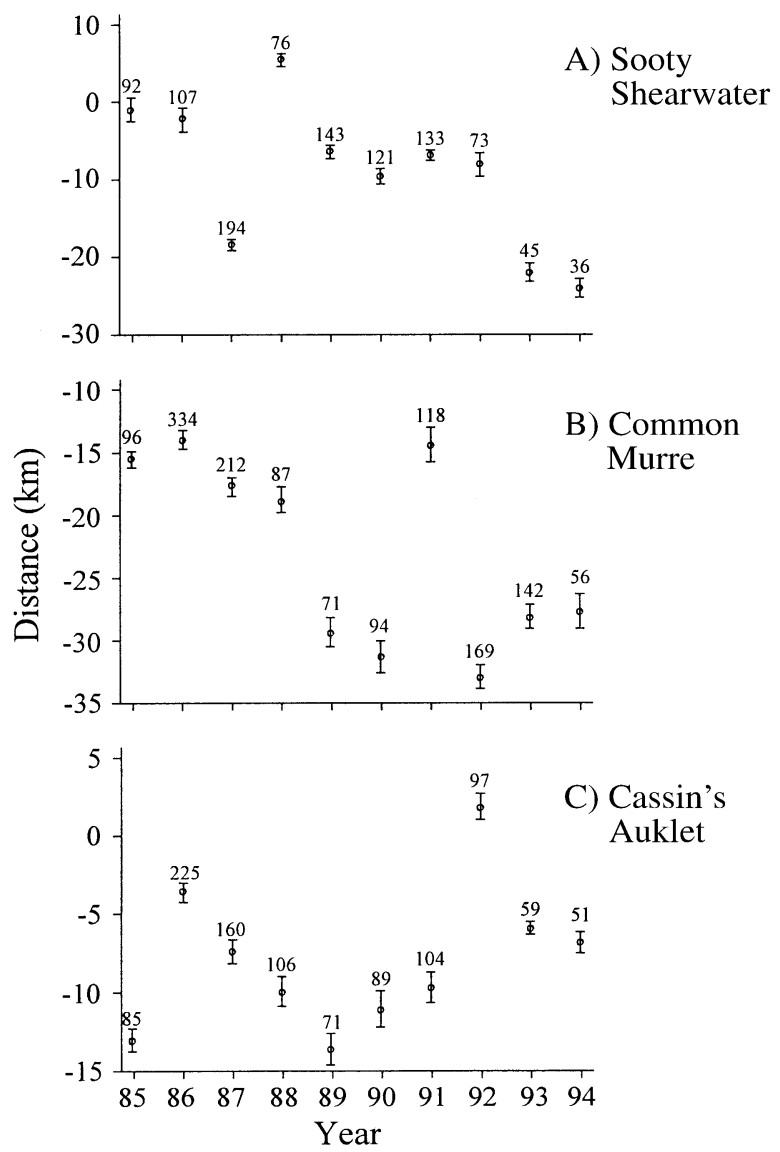

Fig. 5. Puffinus griseus, Uria aalge, and Ptychoramphus aleuticus. Mean $( \pm 1 \mathrm{SE})$ distance for densities of the 3 seabird species relative to distance from the shelfbreak (200 $\mathrm{m}$ isobath). Positive value indicates distribution offshore of the shelfbreak, negative value indicates distribution inshore of the shelfbreak. Numbers adjacent to means: sample sizes (i.e. number of transects in which at least 1 bird was recorded). Means were calculated after samples were weighted by their respective density values

Table 6. Uria aalge. Summary of interactions, including regression slope tendency (negative vs positive coefficients) and p-values for relationship between density of common murres and environmental variables, given for the different strata designated for the second interaction variable. ns = insignificant (slope tendency not shown). All interaction terms analyzed as continuous

\begin{tabular}{|c|c|c|c|c|c|c|c|c|c|c|}
\hline Year & 1985 & 1986 & 1987 & 1988 & 1989 & 1990 & 1991 & 1992 & 1993 & 1994 \\
\hline SST & ns & $(-) 0.015$ & $(-)<0.001$ & ns & $(-)<0.001$ & $(-)<0.001$ & $(+)<0.001$ & $(+)<0.001$ & $(-)<0.001$ & ns \\
\hline TSLP & - & - & $(-)<0.001$ & ns & $(-)<0.001$ & $(-)<0.001$ & $(+)<0.020$ & ns & $(-)<0.004$ & ns \\
\hline Shelf & $(-)<0.001$ & $(-)<0.001$ & $(-)<0.001$ & $(-)<0.001$ & $(-)<0.001$ & $(-)<0.001$ & $(-)<0.001$ & $(-)<0.001$ & $(-)<0.001$ & $(-)<0.001$ \\
\hline Land & $(-)<0.001$ & $(-)<0.001$ & $(-)<0.001$ & $(-)<0.001$ & $(-)<0.001$ & $(-)<0.001$ & $(-)<0.001$ & $(-)<0.001$ & $(-)<0.001$ & $(-)<0.001$ \\
\hline SEFI & $(-)<0.001$ & $(-)<0.001$ & $(-)<0.001$ & $(-)<0.001$ & $(-)<0.001$ & $(-)<0.001$ & $(-)<0.001$ & ns & $(-)<0.001$ & $(-)<0.001$ \\
\hline \multicolumn{11}{|c|}{ SST stratum } \\
\hline & $9.3^{\circ} \mathrm{C}$ & \multicolumn{2}{|c|}{$10.5^{\circ} \mathrm{C}$} & $11.5^{\circ} \mathrm{C}$ & \multicolumn{2}{|c|}{$12.5^{\circ} \mathrm{C}$} & $13.5^{\circ} \mathrm{C}$ & \multicolumn{2}{|c|}{$14.5^{\circ} \mathrm{C}$} & $17.3^{\circ} \mathrm{C}$ \\
\hline Shelf & $(-)<0.001$ & \multicolumn{2}{|c|}{$(-)<0.001$} & $(-)<0.001$ & \multicolumn{2}{|c|}{$(-)<0.001$} & $(-)<0.001$ & \multicolumn{2}{|c|}{$(-)<0.001$} & $(-)<0.001$ \\
\hline Land & $(-)<0.001$ & \multicolumn{2}{|c|}{$(-)<0.001$} & $(-)<0.001$ & \multicolumn{2}{|c|}{$(-)<0.001$} & $(-)<0.001$ & \multicolumn{2}{|c|}{$(-)<0.001$} & $(-)<0.001$ \\
\hline
\end{tabular}


Table 7. Ptychoramphus aleuticus. Summary of interactions, including regression slope tendency (negative vs positive coefficients) and p-values for the relationship between density of Cassin's auklet and environmental variables, given for the different strata designated for the second interaction variable. ns = insignificant (slope tendency not shown). All interaction terms analyzed as continuous

\begin{tabular}{|c|c|c|c|c|c|c|c|c|c|c|}
\hline Year & 1985 & 1986 & 1987 & 1988 & 1989 & 1990 & 1991 & 1992 & 1993 & 1994 \\
\hline SST & $\mathrm{ns}$ & $(-)<0.001$ & $(-) 0.05$ & (-) 0.035 & (-) 0.04 & $(-)<0.001$ & (-) 0.004 & $(-) 0.004$ & (-) 0.039 & ns \\
\hline Shelf & $\mathrm{ns}$ & $(+)<0.001$ & (+) 0.001 & (+) 0.04 & $\mathrm{~ns}$ & (-) 0.008 & (-) 0.026 & (+) 0.036 & ns & ns \\
\hline \multicolumn{11}{|c|}{ SST stratum } \\
\hline & & $9.3^{\circ} \mathrm{C}$ & $10.5^{\circ} \mathrm{C}$ & \multicolumn{2}{|c|}{$11.5^{\circ} \mathrm{C}$} & $12.5^{\circ} \mathrm{C}$ & $13.5^{\circ} \mathrm{C}$ & \multicolumn{2}{|c|}{$14.5^{\circ} \mathrm{C}$} & $17.3^{\circ} \mathrm{C}$ \\
\hline Land & & $<0.001$ & ns & \multicolumn{2}{|c|}{$(+)<0.001$} & ns & ns & \multicolumn{2}{|c|}{ (+) 0.048} & $\mathrm{~ns}$ \\
\hline
\end{tabular}

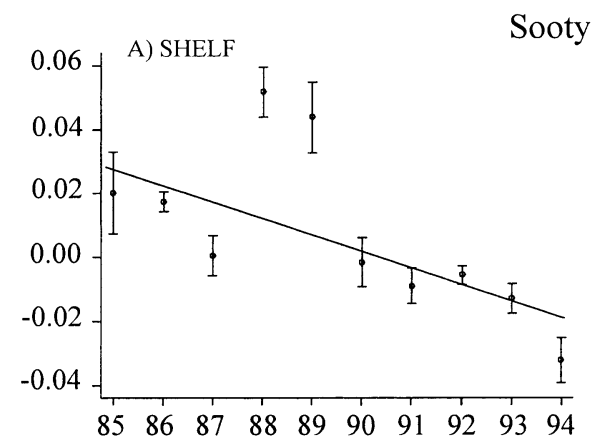

B) LAND

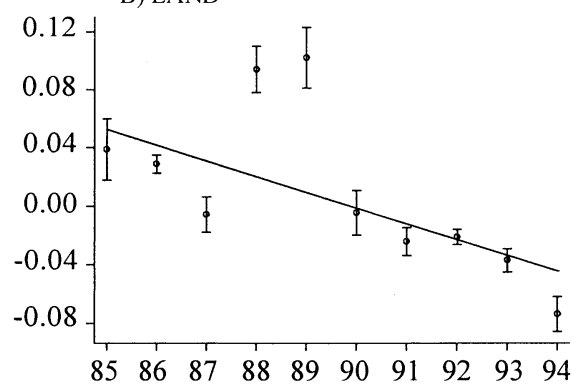

Common Murre
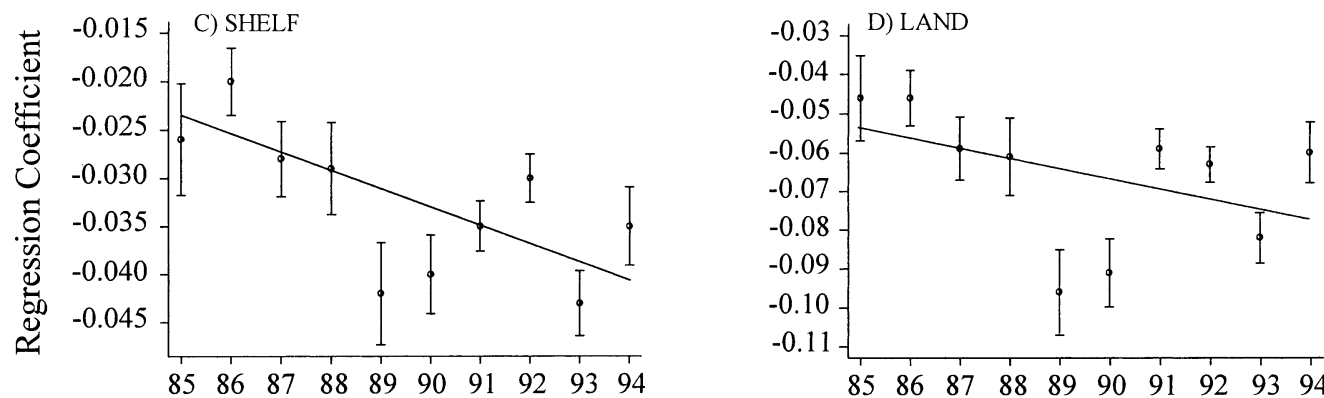

Cassin's Auklet
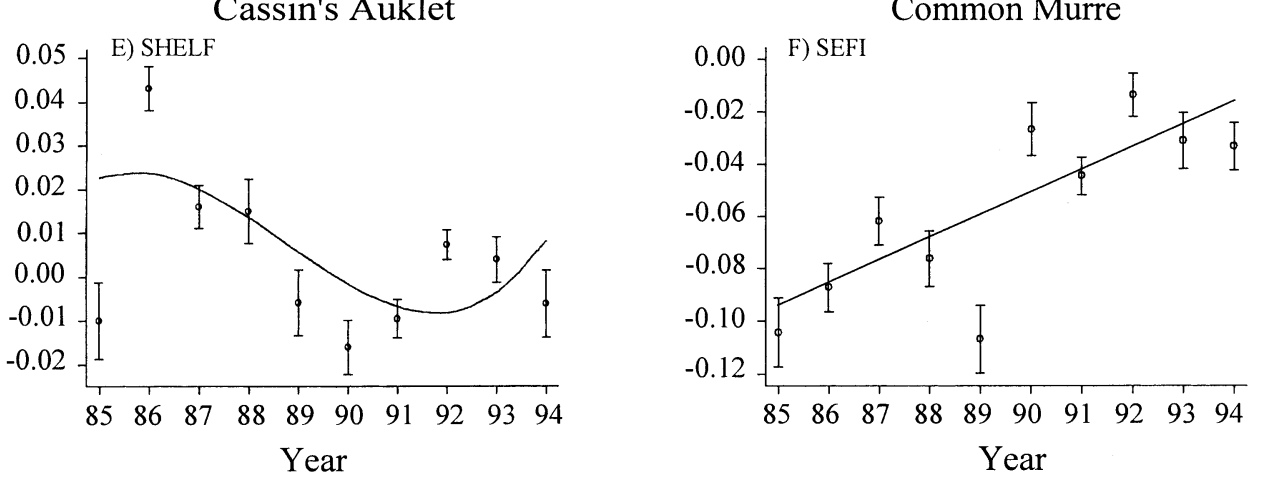

Fig. 6. Puffinus griseus, Uria aalge, and Ptychoramphus aleuticus. Regression coefficients for relationships between density and spatial variables (distance from the shelfbreak $[\mathrm{A}, \mathrm{C}, \mathrm{E}]$, land [B, D] and Southeast Farallon Island [SEFI, F]), stratified by year for the 3 seabird species. ( $($ ) Coefficient means; vertical bars: $\pm 1 \mathrm{SE}$; lines of best fit: relationships between coefficients and year. See Fig. 2A for sample sizes; and Fig. 5 legend for further explanation 
curred near to the shelfbreak. With increase in SST, these birds moved farther inshore of the shelfbreak.

Regression coefficients for the relationship between murre density and distance from the shelfbreak were significantly negative for all SST categories (Table 6, Fig. $7 \mathrm{C}$ ). That is, regardless of changes in SST, murre densities increased with increasing distance from the inshore side of the shelfbreak. There was no linear acrossSST pattern for this relationship (SST analyzed as continuous; see linear term in Table 4). However, there was a quartic relationship due to higher coefficients for SSTs of 8.5 to 10.0 and 12.1 to $14.0^{\circ} \mathrm{C}$, and lower values for SSTs of 10.1 to 11.0 and 14.0 to $19.6^{\circ} \mathrm{C}$. Thus, murre dis- tributions, relative to distance from the shelfbreak, were variable across SSTs, but tended to be closest to shore when SSTs were moderate.

\section{SST $\times$ distance from land}

Similar to the interaction between SST and distance from the shelfbreak, regression coefficients for the relationship between murre density and distance from land were significantly negative for each SST category (Table 6). This indicates that regardless of SST, murre densities increased shoreward. The pattern for the

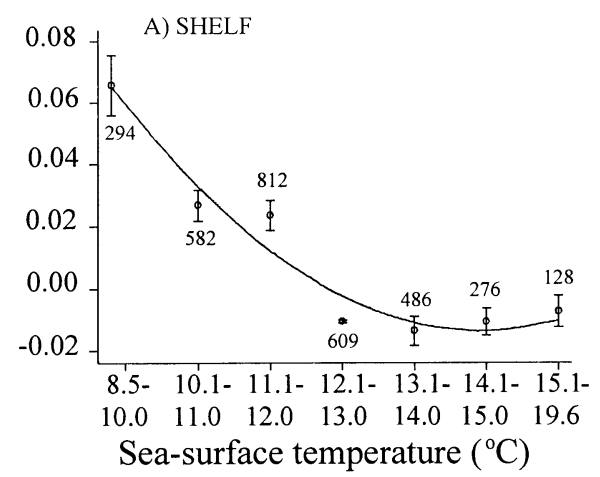

Sooty Shearwater
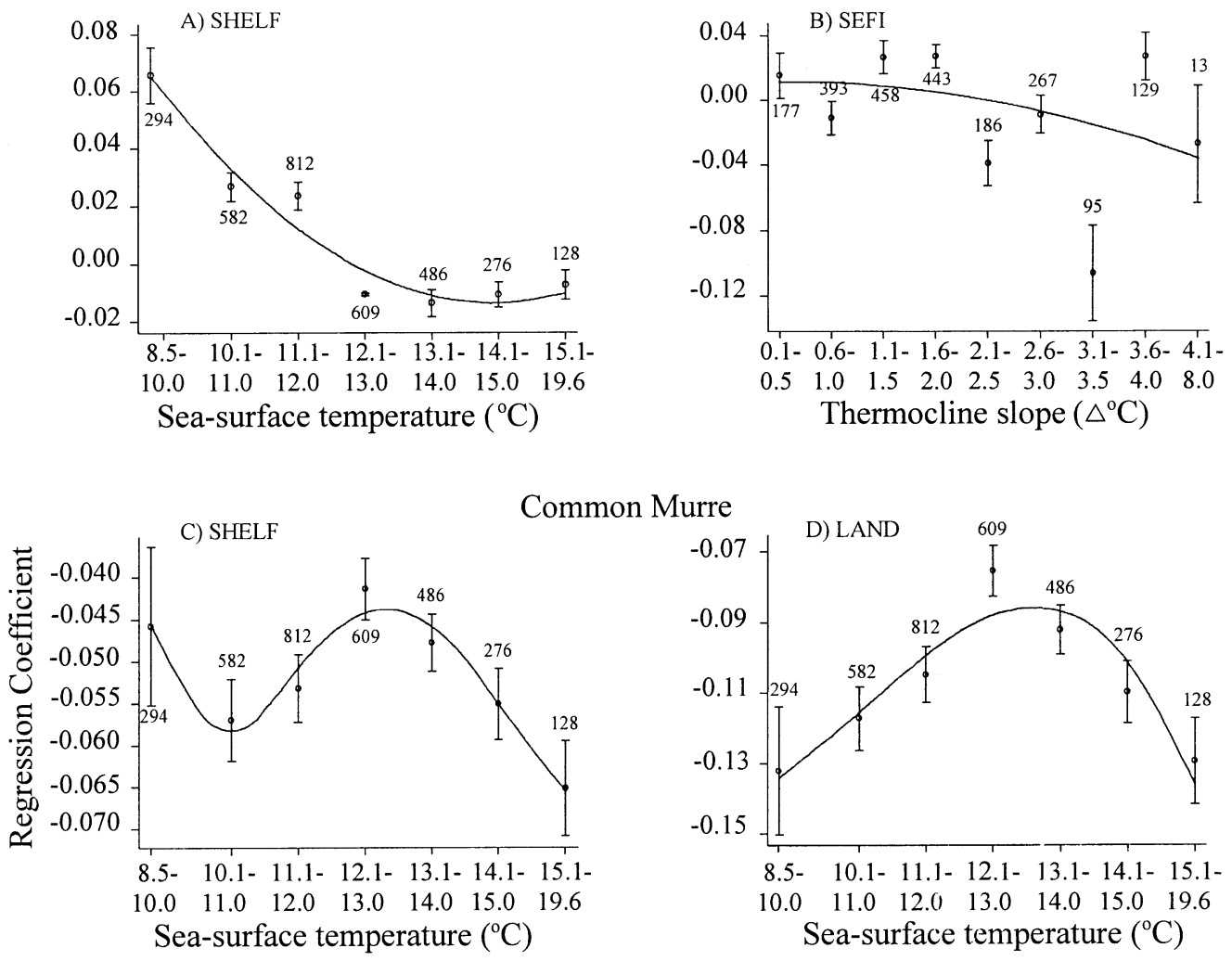

Fig. 7. Puffinus griseus, Uria aalge, and Ptychoramphus aleuticus. Regression coefficients for relationships between density and spatial variables (distance from the shelfbreak [A, C], SEFI $[B]$ and land [D, E]) stratified with respect to SST and thermocline slope for the 3 seabird species. () Coefficients; vertical bars: $\pm 1 \mathrm{SE}_{\text {; }}$ lines of best fit: relationships between coefficient means for the spatial variable and categories for SST/thermocline slope. All variables analyzed as continuous. Numbers next to bars are sample sizes (as explained in Fig. 5)
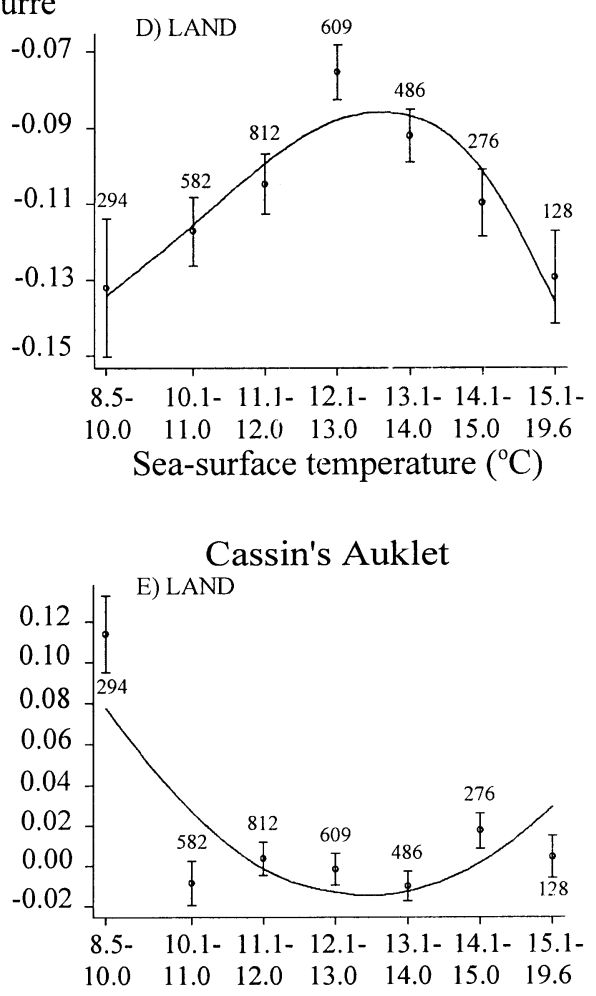

Sea-surface temperature $\left({ }^{\circ} \mathrm{C}\right)$ 
across-SST relationship was cubic (Table 4, Fig. 7D), due to lowest coefficient values at low SSTs, increasingly higher values (to a peak) among moderate SSTs, followed by decreasing and then leveling coefficient values at higher SSTs.

Regression coefficients for the relationship between auklet density and distance from land were significant and positive only for 3 SST categories (Table 7). This indicated that for these SSTs, auklet densities increased with increasing distance from shore. Yet, the across-SST pattern was negative (see linear term in Table 4, Fig. 7E), indicating that with increasing SSTs these birds' selection for more offshore areas diminished. There was also a significant quadratic relationship due to the high, positive coefficient at SSTs of 8.5 to $10.0^{\circ} \mathrm{C}$, low values for 10.1 to $14.0^{\circ} \mathrm{C}$, and leveling or slightly increasing values thereafter.

\section{Thermocline slope $\times$ distance from SEFI}

Regression coefficients for the relationship between shearwater density and distance from SEFI were significant for 4 categories of thermocline slope (Table 5). The 2 positive relationships were for low thermocline slopes (i.e. well-mixed waters), and the reverse was true for the 2 negative relationships. There was a negative, linear across-thermocline slope pattern, as well as a quadratic relationship (Table 4, Fig. 7B), due to the existence of positive coefficients at low thermocline slopes and mostly negative coefficients at higher thermocline slopes. This pattern indicated that shearwater densities increased with increasing distance from SEFI when the water column was well mixed, but that the relationship diminished, or shearwater densities became distributed closer to SEFI, when the water column was more stratified.

\section{DISCUSSION}

\section{Changes in marine environment}

SST was low off central California during the first 5 yr (1985 to 1989) of this study, increased markedly during 1990 to 1993, and then decreased in 1994. Indeed, the highest SSTs occurred during the 1992/ 1993 El Niño. In contrast, SSTs changed little during the 1986/1987 El Niño, i.e. SSTs were similar to those observed during the non-El Niño years of 1985 and 1988. Hence, 'cold-water' years occurred during the 1986/1987 El Niño, and a warm-water year during the non-El Niño year of 1990. Similar patterns held for each of the other environmental variables.

The significant increase in SST during 1985 to 1994 indicated that upwelling of cool, nutrient-rich water had declined. The significant decrease in SSS and the significant increase in thermocline depth also indicated a decrease in upwelling. As noted by Norton \& McLain (1994), a deepened thermocline inhibits the upward infusion of cool, saline, nutrient-rich water to the surface. Accordingly, Roemich \& McGowan (1995) concluded that, due to a surface-intensified warming during recent years, the vertical stratification of the thermocline substantially increased and less cold water came into contact with the upwelling zones. Instead of deep, nutrient-rich water, the source of upwelling became the shallower (warmer) layers above the thermocline, which bore fewer nutrients (thus, less saline). These authors documented an $80 \%$ decrease in macrozooplankton biomass in the California Current from 1951 to 1993, with most of the decrease during latest decades, and related this also to increased SSTs. Indeed, our study (see also Allen 1994) demonstrated that SST was among the most important environmental variables affecting the distributions and abundance of seabird species in the California Current. The following provides details on the relationship between changes in environmental conditions and patterns of spatial and temporal change in the abundance of each of the key seabird species off central California.

\section{Changes in seabird abundance}

\section{Sooty shearwater}

The sooty shearwater Puffinus griseus is the only nonresident species among the 3 key species studied. During the boreal winter, these shearwaters breed on islands off New Zealand and South America (Warham \& Wilson 1982; hereafter, all references to season pertain to the boreal time frame). During spring they migrate to the Peru Current and the North Pacific and become the most abundant seabird in the California Current (and our study area) during the upwelling season (Ainley 1976, Briggs et al. 1987, Ainley et al. 1995b, Veit et al. 1997, Spear \& Ainley 1999).

Unlike breeding residents (the murre and auklet), sooty shearwaters were not constrained to the vicinity of their breeding sites during our study period (summer). Thus, changes in shearwater behavior are directly indicative of environmental change, making this species the most immediately responsive of the 3 seabirds to variations in the marine climate off California. Densities of the shearwaters were high during each of the early, cold-water years (1985 to 1989), with the exception of the 1986 El Niño, when SST was the warmest for the pre-1990 period. They then declined abruptly to a consistent low during the warm-water period beginning in 1990, during which the strong El Niño of 1991 to 1993 occurred (Trenberth 1997). Here, it is impor- 
tant to note that 1990, when the marked decline began, was not an El Niño year. Furthermore, no recovery in abundance occurred during the 1994 La Niña, as had occurred during previous La Niñas that followed other El Niños (e.g. following 1982/1983, 1986/1987). In addition, shearwater densities remained low in all years from 1995 to 2000 (Ainley \& Spear unpubl. data). These results are consistent with those reported earlier (Ainley 1976, Allen 1994, Ainley et al. 1995b, Veit et al. 1997).

The decline in abundance of sooty shearwaters in the California Current may have been due to a decline of the breeding population (Lyver et al. 1999). Based on harvesting rates of sooty shearwater chicks by aboriginals from 1978 to 1998 on Evening Island, New Zealand, Lyver et al. concluded that the shearwaters increased from 1978 to 1989, but decreased by more than $40 \%$ from 1989 to 1998 . These findings are consistent with ours, indicating that sooty shearwaters in the California Current started a long-term decline in 1990. However, the population investigated on Evening Island represents only a small fraction of the total population of sooty shearwaters. Therefore, it is difficult to draw conclusions regarding the status of this species, which also breeds in large numbers off Chile (reviewed in Spear \& Ainley 1999).

Although a population decline is possible, it appears that this species also has altered its migration patterns to avoid the California Current (Spear \& Ainley 1999). During a study in the equatorial Pacific from 1984 to 1991 (i.e. overlapping completely the time period of the present study), Spear \& Ainley documented an increase in the number of sooty shearwaters migrating into the central North Pacific after 1988. Flight directions of these shearwaters indicated that most had originated from the Peru Current (probably consisting of birds representing both the Chilean and New Zealand populations), another eastern boundary system. These authors suggested that a change in this species' distribution, indicated by the increased movement into the central North Pacific and concomitant decrease in the California Current, was more widespread, including shifts to more pelagic wintering areas from both boundary current systems (both of which have experienced simultaneous warming). In recent decades, the productivity of the central North Pacific had been increasing (McGowan et al. 1998).

\section{Common murre}

The common murre Uria aalge breeds on islands located in central California waters during the spring and summer. The major breeding population of the region is on the Farallon Islands. The relatively stable densities that we observed, with highest numbers in 1987 (a slight decline thereafter), was nearly opposite to the trends reported for the breeding population on the Farallon Islands (Sydeman et al. 1996). Sydeman et al. reported lowest population size in 1987 and a slow continuous growth after 1989, with the exception of a short-term decline during 1992/1993.

The differences between results of these 2 studies might reflect that lower food availability in the early 1990s had yet to affect the breeding population on the Farallon Islands, but may have resulted in a poorer survival of fledged young. This could lead to an eventual decrease in the size of the subadult population, which primarily remains at sea and does not recruit into the breeding population until an average age of 5 yr (Hudson 1985). This could explain the stability or slight decrease during the 1990s in the at-sea estimate from this study. Similarly, the presence of a large subadult population during the late-1980s, recruiting in the 1990s, could also help explain the pattern seen in our study and in that of Sydeman et al. (1996).

\section{Cassin's auklet}

The Cassin's auklet Ptychoramphus aleuticus colony on SEFI is $600 \mathrm{~km}$ from the nearest colonies of this species to the north and south (Carter et al. 1992). Therefore, Cassin's auklets seen in central California waters are almost assuredly associated with SEFI. The dramatic decline in at-sea abundance of this species is in accord with a decline in the nesting population on SEFI (Ainley et al. 1994). Ainley et al. (1996a) suggested that this decline reflected the decline in abundance of zooplankton (see below).

\section{Changes in species' distributions}

\section{Relation with feeding ecology}

Our PC analyses indicated that distance from land and distance from the shelfbreak were the most important spatial variables explaining variation in shearwater and auklet at-sea densities. For the murre, the most important variables were distances from land and from SEFI. As mentioned above, the most abrupt changes in shearwater and auklet abundance took place after 1989, when SSTs increased to unusually high levels. It was also after 1989 that a shift in seabird distributions occurred in the central California Current. That is, the distributions of individuals remaining after 1989 shifted increasingly from waters near the shelfbreak to waters nearer to the coast. 
Indeed, the inshore shift in distributions was strongly correlated to the increase in SST, as indicated by the relationships between SST and distance from the shelfbreak or land. In other words, with increase in SST, seabird preference for waters inshore of the shelfbreak increased. The shift was strongest in the shearwater and auklet. In the following, we relate changes in distributions and response to environmental variables to feeding ecology.

\section{Sooty shearwater}

During the period of cooler SSTs (and higher oceanic productivity: Roemich \& McGowan 1995) that preceded the 1990s, sooty shearwaters off central California fed primarily on juvenile rockfish Sebastes spp., euphausiids, and squid during spring and early summer (Chu 1984, Briggs \& Chu 1987). They switched to anchovies Engraulis mordax during late summer, coincident with the seasonal decrease in upwelling and increase in SST (Bolin \& Abbott 1963) and with increased density of schools of these fish near shore (Vrooman et al. 1981, Bence et al. 1992). Before 1990, juvenile rockfish were abundant over the outer continental shelf and upper slope during spring (MacGregor 1986, Echeverria 1987, Pearson et al. 1991). Although no direct studies of the sooty shearwater diet have occurred in recent years, no doubt as waters have warmed, rockfish have declined in their diet, as they have in the diet of murres and other California seabirds (Ainley et al. 1993, 1994, 1996a,b).

In contrast, warm water appears to have a positive impact on the abundance of anchovies and the sardines Sardinops sagax. The subspecies of anchovy that occurs off central California ranges from northern Baja California, Mexico, to approximately Point Reyes, California, but has it's major spawning grounds off southern California (Vrooman et al. 1981). Larger anchovies (to $14 \mathrm{~cm}$, but small enough for murres and shearwaters to eat) move north during years of warmer SST (R. H. Parrish pers. comm. in Ainley \& Boekelheide 1990). Lasker (1978) and Parrish et al. (1981) also found that stability of the water column (lack of upwelling) is associated with good reproductive success of the anchovy. In this regard, it seems likely that the inshore movement of the sooty shearwaters that remained in the California Current after 1989 reflected a diet switch to anchovies after the rockfish abundance declined (see Leet et al. 1992, Love et al. 1998).

The warm water has also brought a resurgence in the availability of sardines in the California Current. During our study, however, the sardine was still not abundant.

\section{Common murre}

Like the sooty shearwater (see above), the common murre in central California feeds primarily on juvenile rockfish, anchovies, and the market squid Loligo opalescens (Ainley \& Boekelheide 1990, Ainley et al. 1996b). During warm-water years, juvenile rockfish composed little of the murre's diet, and were replaced by the anchovies that they caught inshore. It seems likely, therefore, that the inshore shift in distribution of the murres we observed was related to the same factors as those responsible for the inshore shift in the sooty shearwater, i.e. a decline in abundance of rockfish (offshore), in combination with an increase in anchovy abundance (inshore).

During cold-water years, murres were most abundant near the Farallones, offshore of the Point Reyes Peninsula and Half Moon Bay (Allen 1994, Oedekoven 1997). Abundances decreased around the islands in warmwater years, but increased immediately south of the Point Reyes Peninsula and in the San Francisco Bay plume. Allen (1994) suggested that more prey were available in this plume than elsewhere when there was a lack of upwelling of nutrient-rich waters in the region.

\section{Cassin's auklet}

The Cassin's auklet is a zooplanktivore that depends on the euphausiid Thysanoessa spinifera for successful breeding (Ainley \& Boekelheide 1990). The auklet switched from T. spinifera to Euphausia pacifica when upwelling decreased (Ainley et al. 1996a). During coldwater years, $T$. spinifera was most abundant over the shelf (inshore of the shelfbreak front), whereas E. pacifica was usually found in offshore waters. T. spinifera is larger (with many gravid females during spring: Smith \& Adams 1988) than E. pacifica, and therefore of higher energetic value. T. spinifera may be critical to the life history of the auklet, as indicated in the complete overlap of their respective ranges (Vermeer 1981).

In view of the above, the overall trend for an inshore movement of auklets as water temperatures increased was curious. Given that Euphausia pacifica was the primary prey during warm-water years, we expected that the auklets would have moved further offshore. However, in the following, we argue that the auklets' inshore movement was related to changes in the location of the shelfbreak front and a possible effect on the auklet's prey.

Schwing et al. (1991) found that the shelfbreak front, generally located along the shelfbreak, separates warm off-shelf waters with low productivity from colder high-productivity waters over the continental 
shelf. In response to strong upwelling, this front moves farther from the coast; with weak upwelling it disappears or moves toward the coast. The shelfbreak front, when present, also separates the habitats of the 2 euphausiids (see above).

We suggest that the auklets' more offshore distribution during cold-water years was due to 2 factors. First, in cooler-water years when the shelfbreak front and associated upwelling is strong and well offshore (at or beyond the $200 \mathrm{~m}$ isobath), swarms of Thysanoessa spinifera are abundant and also located over the outer shelf even beyond the $200 \mathrm{~m}$ isobath. Second, during warm-water years, when T. spinifera abundance was low and the shelfbreak front was absent or weak, Euphausia pacifica was the only abundant prey and was located near to or even inshore of the $200 \mathrm{~m}$ isobath.

It follows that the general decrease in upwelling during our study period led to a shoreward movement of the shelfbreak front and a general decline in abundance of Thysanoessa spinifera. Auklets were forced to switch to Euphausia pacifica, particularly during the 2 El Niños. In addition, an intensification of the Aleutian Low Pressure System during the early 1990s probably contributed to the inshore intrusion of normally offshore waters (see above; Norton \& McLain 1994). This would have caused the along-shelf front to move inshore, or even disappear, and a spread of the habitat of E. pacifica into inshore areas.

\section{Changes related to life-history strategies of the 2 piscivores}

Changes in the distribution and abundance of the shearwater and murre lead us to conclude that each used a different strategy to cope with a decline in food availability. The strategies are consistent with their respective morphologies and foraging behaviors. The vast majority of the shearwaters left the area, with an inshore redistribution of the few that stayed (see above). The murres, however, remained, although they also moved inshore.

Both species are heavy-bodied birds that forage beneath the sea surface using wing propulsion. Although the shearwater and murre have similar mass (800 and $1000 \mathrm{~g}$, respectively), the shearwater has lower wing loading and a higher aspect ratio (Spear \& Ainley 1997). Thus, it is capable of moving long distances quickly (Spear \& Ainley 1999), but sacrifices diving mobility due to its larger wings (maximum depth recorded $=67 \mathrm{~m}$ : Weimerskirch \& Sagar 1996). In contrast, the murre is a highly specialized diver that can reach depths of $180 \mathrm{~m}$ (Piatt \& Nettleship 1985), but it sacrifices flight mobility due to its smaller wings and very high wing loading. It follows that the less-efficient flight of the murre makes it more dependent on its ability to search a range of subsurface habitats for predictable food, whereas the less-efficient diving ability of the shearwater makes it more dependent on searching wider areas of ocean surface for less-predictable food (Ainley 1977, Crawford \& Shelton 1978, Spear \& Ainley 1997). Hence, the murre was the only successful resident of the 3 key species because it could exploit a wider variety of subsurface habitats (compare shearwater vs murre diets in the Gulf of the Farallones: Chu 1984, Ainley et al. 1996b) in an area where the shallow waters of the continental shelf provide many foraging habitats.

\section{Summary}

El Niño has been considered a primary factor affecting temporary declines in seabird abundance in the California Current (Ainley et al. 1995a). Evidence from this study supports this idea, but also supports the conclusions of Veit et al. (1996) that long-term factors are important. Evident in the present study were corresponding large- and small-scale changes in distributions as well. Examination of the environmental changes during our $10 \mathrm{yr}$ study indicated the importance of both El Niño (1986/1987, and 1991 to 1993) and the Pacific Decadal Oscillation. Not only did seabird declines begin in a non-El Niño year (1990) but, after the 1991 to 1993 El Niño, the sooty shearwater and Cassin's auklet populations showed no recovery in the cold-water, during the 1994 La Niña (or during the 1999 La Niña, following the 1997/1998 El Niño: Ainley \& Spear unpubl. data). Both the severity of the declines (lowest shearwater and auklet densities in 25 yr) and lack of recovery were unprecedented. Prior to the 1990s, seabird populations in the California Current rebounded quickly after El Niño (Ainley \& Boekelheide 1990, Ainley \& Divoky 2000).

Acknowledgements. Cruises were conducted from the National Oceanic and Atmospheric Administration (NOAA) research vessel 'David Starr Jordan'. We thank Chuck Alexander, Sarah Allen, Ian Gaffney, Denise Hardesty, Peter Pyle, and Peter Ryan for their assistance at sea. Personnel of the National Marine Fisheries Service (NMFS) Tiburon Laboratory, William Lenarz, Steve Ralston, and David Woodbury, helped coordinate the survey effort. This study was funded in part by the US Fish \& Wildlife Service, NMFS, and Environmental Protection Agency.

\section{LITERATURE CITED}

Ainley DG (1976) The occurrence of seabirds in the coastal region of California. West Birds 7:33-68

Ainley DG (1977) Feeding methods in seabirds: a comparison 
of polar and tropical nesting communities in the eastern Pacific Ocean. In: Llano GA (ed) Adaptations within Antarctic ecosystems. Proceedings of the 3rd SCAR Symposium on Antarctic Biology. Smithsonian Institute, Washington, DC, p 669-685

Ainley DG, Boekelheide RJ (eds) (1990) Seabirds of the Farallon Islands. Ecology, structure and dynamics of an upwelling system community. Stanford University Press, Palo Alto, CA

Ainley DG, Divoky GL (2000) Birds: seabird responses to global/climate change. In: Steele J (ed) Encyclopedia of ocean Siences. Academic Press, London (in press)

Ainley DG, Sydeman WJ, Parrish RH, Lenarz WH (1993) Oceanic factors influencing distribution of young rockfish (Sebastes) in Central California: a predator's perspective. Calif Coop Ocean Fish Invest Rep 34:133-139

Ainley DG, Sydeman WJ, Hatch SA, Wilson UW (1994) Seabird population trends along the west coast of North America: causes and the extent of regional concordance. Stud Avian Biol 15:119-133

Ainley DG, Sydeman WJ, Norton G (1995a) Upper trophic level predators indicate positive and negative anomalies in the California Current food web. Mar Ecol Prog Ser 118:69-79

Ainley DG, Veit RL, Allen SG, Spear LB, Pyle P (1995b) Variations in marine bird communities of the California Current, 1986-1994. Calif Coop Ocean Fish Invest Rep 36: $72-77$

Ainley DG, Spear LB, Allen SG (1996a) Variation in the diet of Cassin's auklet reveals spatial, seasonal, and decadal occurrence patterns of euphausiids off California, USA. Mar Ecol Prog Ser 137:1-10

Ainley DG, Spear LB, Allen SG, Ribic CA (1996b) Temporal and spatial patterns in the diet of the Common Murre in California waters. Condor 98:691-705

Allen SG (1994) The distribution and abundance of marine birds and mammals in the Gulf of the Farallones and adjacent waters, 1985-1992. PhD dissertation, University of California, Berkeley

Bakun A (1990) Global climate change and intensification of coastal ocean upwelling. Science 247:198-201

Barber RT, Chavez FP (1983) Biological consequences of El Niño. Science 222:1203-1210

Bence JR, Roberts D, Lenarz WH (1992) An evaluation of the spatial distribution of fishes and invertebrates off central California in relation to EPA study areas with emphasis on midwater ichthyofauna. National Marine Fisheries Service, Tiburon, CA (Rep to US EPA Region IX)

Bolin RL, Abbott DP (1962) Studies on the marine climate and phytoplankton of the central coastal area of California, 1954-1960. Calif Coop Ocean Fish Invest Rep 9:23-45

Briggs KT, Chu EW (1987) Trophic relationships and food requirements of California seabirds: updating models of trophic impact. In: Croxall JP (ed) Seabirds-feeding ecology and role in marine ecosystems. Cambridge University Press, New York, NY, p 279-304

Briggs KT, Breck Tyler WM, Lewis DB, Carlson DR (1987) Bird communities at sea off California: 1975 to 1983. Stud Avian Biol 11:1-74

Cane MA (1983) Oceanographic events during El Niño. Science 222:1189-1195

Carter HR, McChesney GJ, Jacques DL, Strong CS, Parker MW, Takekawa JE, Jory DL, Whitworth DL (1992) Breeding populations of seabirds on the northern and central California coasts in 1989-1991. US Department of the Interior, Ministry Management Service, Los Angeles, CA

Chelton DB (1981) Interannual variability of the California
Current-physical factors. Calif Coop Ocean Fish Invest Rep 22:34-48

Chelton DB, Bernal PA, McGowan JA (1982) Large-scale interannual physical and biological interaction in the California Current. J Mar Res 40:1095-1125

Chu EW (1984) Sooty shearwaters off California: diet and energy gain. In: Nettleship DN, Sanger GA, Springer PF (eds) Marine birds: their feeding ecology and commercial fisheries relationships. Canadian Wildlife Service, Dartmouth, Nova Scotia, p 64-71

Crawford RJM, Shelton PA (1978) Pelagic fish and seabird interrelationships off the coast of Southwest and South Africa. Biol Conserv 14:85-109

Echeverria TW (1987) Thirty-four species of California rockfishes: maturity and seasonality of reproduction. US Natl Mar Fish Serv Fish Bull 85:229-250

Enfield DB (1981) El Niño: Pacific eastern boundary response to interannual forcing. In: Glantz MH, Thompson JD (eds) Resource management and environmental uncertainty. John Wiley \& Sons Inc, New York, NY, p 213-245

Hastie T, Tibshirani RJ (1990) Generalized additive models. Chapman \& Hall, London

Hayward TL, Cummings SL, Cayan DR, Chavez FP, Lynn RJ, Mantyla AW, Niiler PP, Schwing FB, Veit RR, Venrick EL (1996) The state of the California Current in 1995-1996: continuing declines in macrozooplankton biomass during a period of nearly normal circulation. Calif Coop Ocean Fish Invest Rep 37:22-37

Hickey BM (1979) The California Current system-hypothesis and facts. Progr Oceanogr 8:191-279

Hudson PJ (1985) Population parameters for the Atlantic alcidae. In: Nettleship DN, Birkhead TR (eds) The Atlantic Alcidae. Academic Press, Orlando, FL, p 233-263

Lasker R (1978) The relation between oceanographic conditions and larval anchovy food in the California Current: identification of factors contributing to recruitment failure. Rapp P-V Réun Cons Int Explor Mer 173:212-230

Leet WS, Dewees CM, Haugen CW (1992) California's living marine resources and their utilization. Univ Calif, Davis (California Sea Grant Extension Publ, UCSGEP-92-12)

Love MS, Caselle JE, van Buskirk W (1998) A severe decline in the commercial passenger fishing vessel rockfish (Sebastes spp.) catch in the Southern California Bight, 1980-1996. Calif Coop Ocean Fish Invest Rep 39:180-195

Lyver POB, Moller H, Thompson C (1999) Changes in sooty shearwater Puffinus griseus chick production and harvest precede ENSO events. Mar Ecol Prog Ser 188:237-248

MacGregor JS (1986) Relative abundance of four species of Sebastes off California and Baja California. Calif Coop Ocean Fish Invest Rep 27:121-135

Mantua NJ, Hare SR, Zhang Y, Wallace JM, Francis RC (1997) A Pacific-interdecadal climate oscillation with impacts on salmon production. Bull Am Meteorol Soc 78: 1069-1079

McGowan JA, Chelton DB, Conversi A (1996) Plankton patterns, climate, and change in the California Current. Calif Coop Ocean Fish Invest Rep 37:45-68

McGowan JA, Cayan DR, Dorman LM (1998) Climate-ocean variability and ecosystem response in the Northeast Pacific. Science 281:210-217

McLain DR, Brainard RE, Norton JG (1985) Anomalous warm events in eastern boundary current systems. Calif Coop Ocean Fish Invest Rep 24:165-180

Miller AJ, Cayan DR, Barnett TP, Graham NE, Oberhuber JM (1994) The 1976-77 climate shift of the Pacific Ocean. Oceanography 7:21-26

Norton J, McLain D (1994) Diagnostic patterns of seasonal 
and interannual temperature variation off the west coast of the United States: local and remote large scale atmospheric forcing. J Geophys Res 99:16019-16030

Oedekoven CS (1997) Seabird abundances and distribution in the California Current in relation to changes in the marine environment, 1985-1997. Diplom dissertation, University of Bonn

Parrish RH, Nelson CS, Bakun A (1981) Transport mechanisms and reproductive success of fishes in the California Current. Biol Oceanogr 1:175-203

Pearson DE, Hightower JE, Chan JYH (1991) Age growth, and potential yield for shortbelly rockfish Sebastes jordani. US Natl Mar Fish Serv Fish Bull 89:403-409

Piatt JF, Nettleship DN (1985) Diving depths of four alcids. Auk 102:293-297

Roemich D, McGowan JA (1995) Climatic warming and the decline of zooplankton in the California Current. Science 267:1324-1326

Schwing FB, Husby DM, Garfield N, Tracy DE (1991) Mesoscale oceanic response to wind events off Central California in spring 1989: CTD surveys and AVHRR imagery. Calif Coop Ocean Fish Invest Rep 32:47-64

Seber GAF (1977) Linear regression analysis. John Wiley \& Sons, New York

Simpson JJ (1992) Response of the Southern California current system to the mid-latitude North Pacific warming events of 1982-1983 and 1940-1941. Fish Oceanogr 1: $57-79$

Smith SE, Adams PB (1988) Daytime surface swarms of Thysanoessa spinifera (Euphausiacea) in the Gulf of the Farallones, California. Bull Mar Sci 42:76-84

Spear LB, Ainley DG (1997a) Flight behaviour of seabirds in relation to wind direction and wing morphology. Ibis 139: 221-233

Spear LB, Ainley DG (1999) Migration routes of Sooty Shearwaters in the Pacific Ocean. Condor 101:205-218

Spear LB, Nur N, Ainley DG (1992) Estimating absolute den-

Editorial responsibility: Otto Kinne (Editor),

Oldendorf/Luhe, Germany sities of flying seabirds using analyses of relative movement. Auk 109:385-389

STATA Corp. (1995) STATA reference manual: release 5.1, 6th edn. Stata Corporation, College Station, TX

Sydeman WJ, Carter HR, Takekawa JE, Nur N (1996) Common Murre Uria aalge population trends on Southeast Farallon Island and adjacent islets, California, 1985-1995. Point Reyes Bird Observatory, Stinson Beach, US Geological Survey, Dixon, and US Fish \& Wildl Service, Newark, CA

Tasker ML, Hope Jones P, Dixon T, Blake BF (1984) Counting seabirds at sea from ships: a review of methods employed and a suggestion for a standardized approach. Auk 101: 567-577

Trenberth KE (1997) The definition of El Niño. Bull Am Meteorol Soc 78:2771-2777

Veit RR, Pyle P, McGowan JA (1996) Ocean warming and long-term change in pelagic bird abundance within the California Current system. Mar Ecol Prog Ser 139:11-18

Veit RR, McGowan JA, Ainley DG, Wahl TR, Pyle P (1997) Apex marine predator declines ninety percent in association with changing oceanic climate. Glob Change Biol 3: $23-28$

Vermeer K (1981) The importance of plankton to Cassin's auklets during breeding. J Plankton Res 3:315-329

Vrooman AM, Palona PA, Zweifel JR (1981) Electrophoretic, morphometric, and meristic studies of subpopulations of Northern anchovy, Engraulis mordax. Calif Fish Game 67: 39-51

Warham J, Wilson GJ (1982) The size of the Sooty Shearwater population at the Snares Islands, New Zealand. Notornis 29:23-30

Weimerskirch H, Sagar PM (1996) Diving depth of Sooty Shearwaters Puffinus griseus. Ibis 138:786-788

Wyrtki K (1975) El Niño-the dynamic response of the equatorial Pacific Ocean to atmospheric forcing. J Phys Oceanogr 5:572-84

Submitted: July 24, 1999; Accepted: July 25, 2000 Proofs received from author(s): February 13, 2001 